\title{
KAJIAN PELAKSANAAN PENATAUSAHAAN HASIL HUTAN RAKYAT DI KABUPATEN CILACAP ${ }^{1)}$ The Study of Forest Product Administration Implementation Community Forest in Cilacap Region
}

\author{
Oleh / By : \\ Epi Syahadat \& Rachman Effendi ${ }^{2)}$
}

\begin{abstract}
Forest product administration in community forest is not in good and proper arrange and it's implementation can not sustain the forest and collect the optimum forest product revenue. The study was conducted on forest product administration in community forest aiming to find out the policy district issued could belped and created the forest product administration in proper. The study is conducted by reviewing district timber administration policy in community forest, and its compatibility with higher law (ministry decree).

The study result showed that there are intent in the timber administration in Cilacap Region regulation from community forest which should be reviwed in order to encourage the sustain ability of community forest. Reviewed should be made to simplified the regulation, starting from cutting permit untill to the transporting permit.
\end{abstract}

Key word: Private forest, forestproduct management, usage, rotation, transportation

\begin{abstract}
ABSTRAK
Penatausahaan hasil hutan di hutan rakyat belum tertata dengan baik dan di dalam pelaksanaannya masih memerlukan penanganan dan perhatian yang serius baik oleh pihak pemerintah maupun masyarakat. Secara umum penatausahaan hasil hutan baik di hutan alam, hutan tanaman maupun di hutan rakyat masih belum mampu menjamin kelestarian hutan dan penerimaan negara atas hasil hutan secara optimal. Kajian pelaksanaan penatausahaan hasil hutan rakyat di Kabupaten Cilacap yang dilakukan adalah untuk mengetahui sejauh mana kebijakan yang diterbitkan oleh Pemerintah Daerah setempat dapat membantu dalam menyelesaikan permasalahan mengenai penatausahaan hasil hutan rakyat yang baik dan benar sesuai dengan kebijakan penatausahaan hasil hutan yang dikeluarkan oleh pemerintah pusat dalam hal ini adalah Departemen Kehutanan. Kajian ini dilakukan dengan cara melakukan tinjauan atas kebijakan penatausahaan hasil hutan yang diterbitkan oleh Pemda Kabupaten/ Kota setempat dan kemudian dibandingkan dengan peraturan perundangan berlaku pada saat ini.

Hasil kajian menunjukkan bahwa Perda Kabupaten Cilacap Nomor 12/2001, tentang Retribusi Ijin Tebang Di Kabupaten Cilacap, perlu ditinjau dan disempurnakan agar ketertiban, kelancaran, dan tanggung jawab dalam pengelolaan hasil hutan dapat tercipta dengan baik sesuai dengan SK Menteri Kehutanan No. 126/2003, Peraturan Menteri Kehutanan No. P.18/2005, No. P26/2006 dan No. P.51/2006. Penyempurnaan Perda tersebut dimulai dari pengurusan permohonan izin tebang hingga pengangkutan hasil hutan. Perlu adanya berita acara pemeriksaan penebangan sebelum pengesahan LHP, dan dokumen pengangkutan hasil hutan perlu disederhanakan tanpa mengurangi fungsi penatausahaan hasil hutan yang efektif dalam melestarikan hutan dan mejamin hak-hak negara atas hasil hutan.
\end{abstract}

Kata kunci : Penatausahaan hasil hutan, pemanfaatan, peredaran, pengangkutan.

\footnotetext{
${ }^{1)}$ Naskah diterima tanggal 31 Oktober 2006 dan koreksi akhir tanggal 27 Maret 2007

${ }^{2)}$ Peneliti pada Puslitsosek, alamat Jl. Gunung Batu 5 Bogor
} 


\section{PENDAHULUAN}

Permintaan kayu sebagai bahan baku industri pengolahan kayu maupun kebutuhan kayu rumah tangga sulit untuk dikurangi, sementara potensi kayu dari hutan alam sebagai penghasil kayu bagi pembangunan nasional semakin hari semakin menurun. Oleh karenanya salah satu alternatif untuk memenuhi kebutuhan tersebut melalui pengembangan hutan rakyat. Hutan rakyat disamping mempunyai fungsi pendukung lingkungan, konservasi tanah dan perlindungan tata air juga mempunyai kontribusi yang cukup besar dalam upaya pemenuhan kebutuhan bahan baku kayu.

Mengingat bahwa kayu rakyat adalah hasil hutan yang diperoleh dari lahan milik sendiri, maka pengolahan dan pemanfaatan hasil hutan sepenuhnya menjadi hak milik mereka, sedangkan fungsi pemerintah dalam hal ini hanya melakukan pembinaan untuk menjamin kelestarian hutan. Untuk itu di dalam upaya melaksanakan penatausahaan hasil hutan yang baik, efisien, efektif dan lestari, maka Departemen Kehutanan sebagai unit kerja atau institusi yang bertanggung jawab penuh terhadap semua permasalahan kehutanan telah mengeluarkan peraturan perundangan mengenai penatausahaan hasil hutan, yaitu Surat Keputusan Menteri Kehutanan Nomor 126/Kpts-II/2003. Dalam SK tersebut semua permasalahan mengenai penatausahaan hasil hutan atau peredaran kayu baik yang berasal dari hutan alam, hutan tanaman, dan hutan rakyat mulai dari pembuatan LHC, RKT, LHP, dokumen angkutan (SKSHH) dan lain sebagainya diuraikan dengan jelas. Seiring dengan berjalannya waktu dan perubahan kebijakan mengenai politik, ekonomi, sosial, budaya, pertahanan keamanan di negara Indonesia, SK tersebut mengalami perubahan, akan tetapi pada dasarnya adalah untuk terselenggaranya penatausahaan hasil hutan yang baik, efisien, efektif dan lestari sesuai dengan visi dan misi pembangunan kehutanan di Indonesia.

Khusus dalam pemanfaatan hasil hutan dari hutan rakyat, Departemen Kehutanan telah mengeluarkan peraturan tersendiri, yaitu Peraturan Menteri Kehutanan Nomor P.26/Menhut-II/2005 tentang Pedoman Pemanfaatan Hutan Hak/Rakyat. Di dalam Permenhut tersebut diuraikan bahwa fungsi hutan rakyat ada 3 (tiga), yaitu : a. Fungsi Konservasi, b. Fungsi Lindung, dan c. Fungsi Produksi. Sedangkan pemanfaatan hutan rakyat yang berfungsi produksi dapat berupa : a. Pemanfaatan hasil hutan kayu, b. Pemanfaatan hasil hutan bukan kayu, dan c. Pemanfaatan jasa lingkungan (Anonim, 2005). Walaupun dalam pemanfaatan hutan rakyat pemerintah telah menerbitkan peraturan perundangan tersendiri, yaitu Permenhut No. P.26/2005, akan tetapi dalam Permenhut tersebut belum secara rinci mengatur mengenai penatausahaan hasil hutannya atau dengan perkataan lain penatausahaan hasil hutan dari hutan rakyat masih mengacu pada SK Menteri Kehutanan No. 126/2003.

Permasalahan dalam penatausahaan hasil hutan di hutan rakyat atau dalam peredaran kayu rakyat, adalah sebagai berikut (Syahadat E., 2006):

1. Harga kayu di tingkat petani rendah, karena biasanya petani menjual kayu tersebut ke pedagang pengumpul (tengkulak) atas dasar kebutuhan dana meskipun umur pohon tersebut belum masak tebang (daur butuh).

2. Adanya persyaratan yang harus dipenuhi dalam membuat rencana penebangan (ijin tebang), seperti harus melampiri peta areal hutan hak/rakyat yang harus diketahui oleh Camat setempat, melampirkan laporan potensi tegakan dan lain sebagainya, sehingga dalam pengurusannya terkesan rumit.

3. Karena tidak adanya petunjuk teknis, maka akan timbul permasalahan dalam penatausahaan hasil hutan dengan adanya otonomi daerah. 
4. Daerah tujuan kayu tidak memperoleh bagian insentif dari kayu yang diproduksi di daerah lain (asal kayu), sehingga daerah tujuan kayu tidak mempunyai dana koordinasi yang diperlukan oleh pemerintah setempat dalam melakukan pengawasan terhadap peredaran kayu rakyat yang ilegal (illegal logging)

5. Dalam pengangkutan kayu rakyat, penggunaan SKSHH yang di cap KR sebagai dokumen pengangkutan kayu rakyat untuk beberapa jenis kayu di luar jenis kayu rakyat yang dalam pengangkutannya menggunakan SKAU sebagai dokumen pengangkutan resmi kayu rakyat, sesuai dengan Permenhut Nomor 51/2006, masih memberatkan para petani.

6. Kurangnya pengawasan yang dilakukan oleh petugas kehutanan terhadap peredaran kayu rakyat ketika kayu yang berasal dari satu daerah sampai di tempat tujuan kayu, atau ketika kayu dari luar daerah masuk ke daerah tujuan kayu di Kabupaten/Kota.

Berdasarkan permasalan tersebut diatas maka tujuan penelitian ini, adalah sebagai berikut :

1. Untuk mengetahui sejauhmana kebijakan yang dibuat oleh Pemerintah Daerah Kabupaten/Kota setempat dapat membantu dalam menyelesaikan permasalahan mengenai penatausahaan hasil hutan di hutan rakyat.

2. Terselenggaranya penatausahaan hasil hutan yang sederhana, tertib, lancar sesuai dengan potensi yang dimiliki.

Sasaran yang akan dicapai kajian ini, adalah :

1. Pengamanan terhadap berbagai kepentingan negara, seperti kelestarian hutan di hutan rakyat dan pengembangan pembangunan hutan rakyat itu sendiri.

2. Terciptanya penatausahaan hasil hutan di hutan rakyat yang tertib, lancar, efisien dan bertanggung jawab.

Ruang Lingkup penatausahaan hasil hutan rakyat meliputi semua jenis kayu yang diproduksi dari luar kawasan hutan seperti hutan milik, hutan rakyat, tegalan, kebun atau kawasan perkebunan, mulai dari permohonan surat ijin tebang (SIT), laporan hasil penebangan (LHP), sampai ke permohonan dokumen angkutan (SKSHH).

\section{METODE PENELITIAN}

\section{A. Kerangka Pemikiran}

Kayu rakyat merupakan salah satu komoditas yang memberikan pendapatan bagi masyarakat dan mempunyai kontribusi yang cukup besar dalam upaya pemenuhan bahan baku industri kayu dan rumah tangga. Dalam Peraturan Menteri Kehutanan Nomor P.26/2005 tentang Pedoman Pemanfaatan Hutan Hak/Rakyat, pada pasal 12 ayat (1) dinyatakan pemanfaatan hutan hak dilakukan oleh pemegang hak atas tanah yang bersangkutan sesuai dengan fungsinya, kemudian dalam ayat (2) dinyatakan pemanfaatan hutan hak sebagaimana dimaksud pada ayat (1) bertujuan untuk memperoleh manfaat yang optimal bagi pemegang hak dengan tidak mengurangi fungsinya. Oleh karena itu untuk mencegah kerusakan hutan negara yang kian memprihatinkan akibat perambahan, penjarahan, penebangan liar dan sebagai pengaman dan pengendalian peredaran kayu rakyat di lintas kabupaten, maka dipandang perlu untuk membuat petunjuk pelaksanaan penatausahaan hasil hutan di hutan rakyat oleh Dinas Kehutanan Provinsi setempat, yang kemudian petunjuk pelaksanaan tersebut dijabarkan lebih lanjut oleh Dinas Kehutanan 
Kabupaten/Kota dengan diterbitkannya petunjuk teknis (Juknis) dapat berupa Perda, SK Kepala Daerah setempat, atau lainnya). Apabila kita gambarkan kerangka pemikiran tersebut, adalah sebagai berikut:

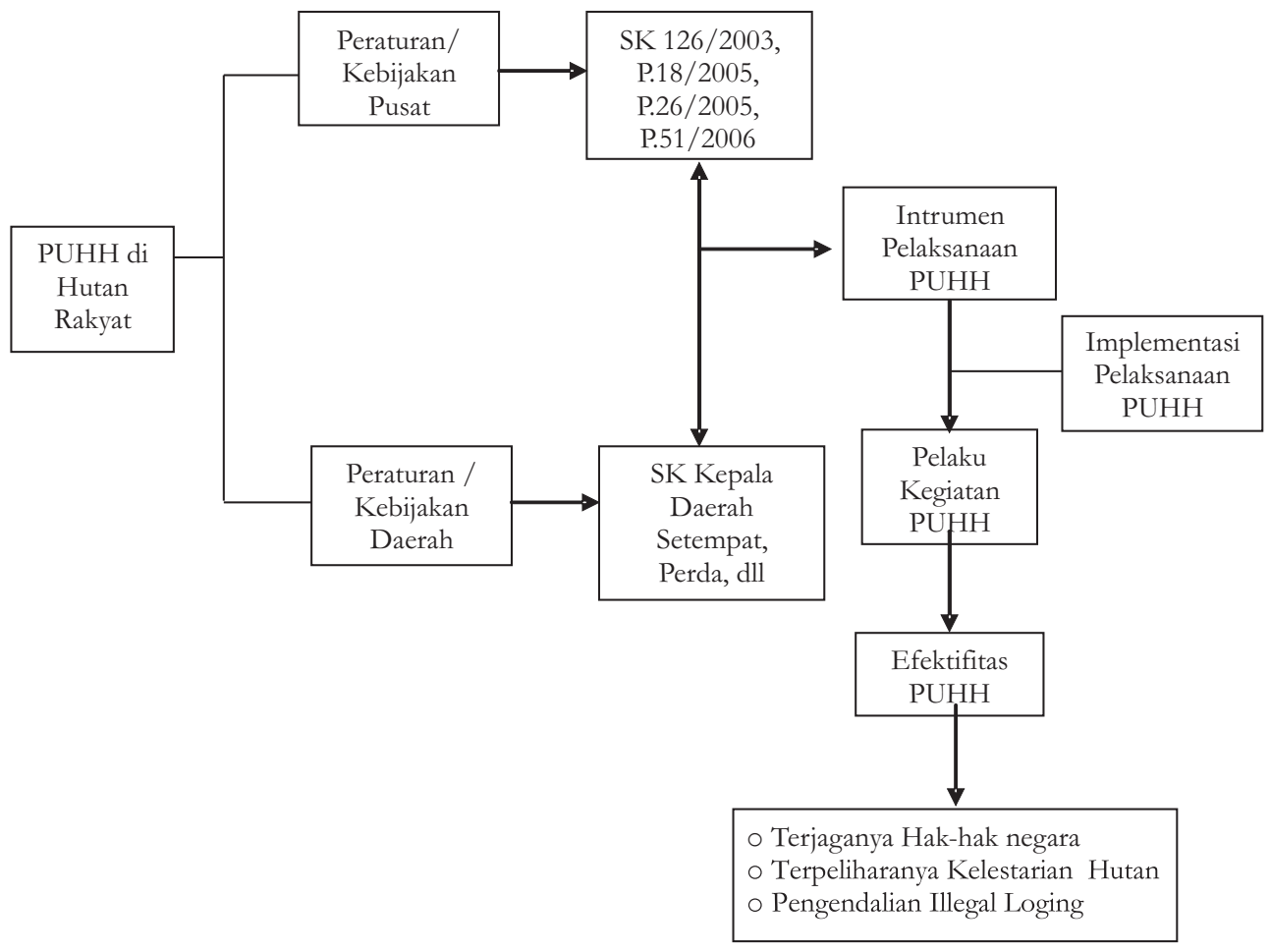

Gambar 1. Kerangka Pemikiran

\section{B. Pengumpulan Data dan Referensi}

Data yang dikumpulkan adalah data primer dan sekunder. Data primer diperoleh melalui pengamatan dan wawancara dengan Pejabat Kehutanan di daerah dan Badan Usaha yang melakukan kegiatan pengelolaan hasil hutan. Data primer yang diperoleh meliputi pelaksanaan penatausahaan kayu, kesenjangan pelaksanaan dan uraian tugas, pengesahan dan penerbitan dokumen penatausahaan hasil hutan, sedangkan data sekunder diperoleh di kantor kehutanan, perusahaan, dan perpustakaan. Adapun data yang diperoleh meliputi potensi hutan (luasan hutan), realisasi produksi hasil hutan, dan lain-lain.

Referensi penatausahaan hasil hutan rakyat adalah sebagai berikut:

1. Peraturan Pemerintah Republik Indonesia Nomor 6, tahun 2007, tentang Tata Hutan dan Penyusunan Rencana Pengelolaan Hutan, Serta Pemanfaatan Hutan.

2. Surat Keputusan Menteri Kehutanan Nomor 126/Kpts-II/2003, tentang Penatausahaan Hasil Hutan.

3. Peraturan Menteri Kehutanan Nomor P.18/Menhut-II/2005, tentang Perubahan Ketiga Atas Keputusan Menteri Kehutanan Nomor 126/Kpts-II/2003, tentang Penatausahaan Hasil Hutan. 
4. Peraturan Menteri Kehutanan Nomor P.26/Menhut-II/2005, tentang Pedoman Pemanfaatan Hutan Hak/Rakyat.

5. Peraturan Menteri Kehutanan Nomor P.51/Menhut-II/2005, tentang Penggunaan Surat Keterangan Asal Usul Kayu (SKAU) Untuk Pengangkutan Hasil Hutan Kayu Yang Berasal Dari Hutan Hak.

\section{Metode Analisis}

Dalam penelitian ini, metode analisis yang digunakan adalah metode analisis deskriptif, dimana dalam mengkaji kebijakan penatausahaan hasil hutan yang dibuat atau yang diterbitkan oleh Pemerintah Daerah Kabupaten / Kota setempat dibandingkan dan disesuaikan dengan perundang-undangan yang berlaku pada saat ini, yaitu Undang-undang Otonomi Daerah No. 32/2004, Peraturan Menteri Kehutanan Nomor P.26/MenhutII/2005, Peraturan Pemerintah No. 6/2007, SK Menteri Kehutanan No 126/Kpts-II/2003, Peraturan Menteri Kehutanan No P.18/Menhut-II/2005, dan Peraturan Menteri Kehutanan No. P.51/Menhut-II/2006.

\section{HASIL PEMBAHASAN}

\section{A. Gambaran Umum dan Potensi Hutan Di Kabupaten Cilacap}

1. Potensi Hutan Di Kabupaten Cilacap

Pada Tabel 1 di bawah dapat dilihat potensi hutan di Kabupaten Cilacap, luas wilayah Kabupaten Cilacap, adalah 213.851 Ha (Anonim, 2004), luas kawasan hutan 50.860,57 Ha atau 23,78\% dari luas wilayah Kabupaten Cilacap, sedangkan wilayah hutan di Kabupaten Cilacap yang terluas adalah kawasan hutan produksi tetap, seluas $31.374,27 \mathrm{Ha}$ atau $61,69 \%$ dari total luas kawasan hutan atau 14,67\% dari luas wilayah Kabupaten Cilacap. Berdasarkan data yang diperoleh dari Dinas Kehutanan Provinsi Jawa Tengah luas hutan rakyat di Provinsi tersebut seluas $219.787,71 \mathrm{Ha}$, sedangkan luas hutan rakyat di Kabupaten Cilacap \pm 14.442 , $49 \mathrm{Ha}$ atau sekitar 6,57\% (Anonim, 2004).

Tabe11. Luas Kawasan Hutan Di Kabupaten Cilacap s/d Juni 2006

\begin{tabular}{|c|l|r|c|}
\hline No & \multicolumn{1}{|c|}{ Uraian } & Luas (Ha) & \multicolumn{1}{c|}{$\%$} \\
\hline 1 & Hutan lindung / Negara & $6.306,10$ & 12,40 \\
\hline 2 & Taman Wisata Alam (TWA) & $1.332,80$ & 2,62 \\
\hline 3 & Hutan Produksi Tetap & $31.374,27$ & 61,69 \\
\hline 4 & Hutan Produksi Terbatas & $11.847,40$ & 23,29 \\
\hline 5 & Hutan Yang Dapat Di Konversi & 0 & 0 \\
\hline 6 & Cagar Alam & $50.860,57$ & 0 \\
\hline & Jumlah & & 100 \\
\hline
\end{tabular}

Sumber : Dinas Kehutanan Kabupaten Cilacap, 2006 


\section{Realisasi Produksi Kayu Di Kabupaten Cilacap}

Pada Tabel 2 di bawah dapat dilihat jumlah produksi kayu non HPH di Kabupaten Cilacap s/d Juni 2006 adalah 75.623,44 Ha (Anonim, 2006) yang terdiri dari kayu bulat, kayu gergajian, dan kayu olahan, dari ketiga jenis produksi kayu tersebut, jumlah produksi kayu yang terbesar adalah kayu olahan, yaitu sebesar $42.725,34 \mathrm{M}^{3}$ atau 56,49\% dari jumlah produksi kayu di Kabupaten Cilacap.

Tabe1 2. Produksi Kayu di Kabupaten Cilacap s/d Juni 2006

\begin{tabular}{|c|l|c|c|c|}
\hline No & \multicolumn{1}{|c|}{ Uraian } & Satuan & Jumlah & $\%$ \\
\hline 1 & Kayu Bulat & $\mathrm{M}^{3}$ & $7.605,31$ & 10,06 \\
\hline 2 & Kayu Gergajian & $\mathrm{M}^{3}$ & $25.292,79$ & 33,45 \\
\hline 3 & Kayu Olahan & $\mathrm{M}^{3}$ & $42.725,34$ & 56,49 \\
\hline 4 & Hasil Hutan Ikutan & - & 0 & 0 \\
\hline & Jumlah & & $75.623,44$ & 100 \\
\hline
\end{tabular}

Sumber : Anonim, 2006

Berdasarkan data yang diperoleh dari Dinas Kehutanan Provinsi Jawa Tengah kemampuan pasokan bahan baku di Provinsi Jawa Tengah sebesar 2,9 juta $\mathrm{M}^{3} /$ tahun yang terdiri dari dari Perum Perhutani Unit I Jawa Tengah sebesar $600.000 \mathrm{M}^{3} /$ tahun, hutan rakyat sebesar $1.700 .000 \mathrm{~m}^{3} /$ tahun dan sisanya kayu dari luar jawa, sedangkan kebutuhan bahan baku industri perkayuan di Provinsi Jawa Tengah sebesar 6 juta $\mathrm{M}^{3} / \operatorname{tahun}$ (Anonim, 2004).

\section{B. Penatausahaan Hasil Hutan Di Hutan Hak/Rakyat}

1. Pemanfaatan Hasil Hutan di Hutan Hak/Rakyat

Pemanfaatan hutan hak/rakyat diatur berdasarkan Peraturan Menteri Kehutanan Nomor P.26/Menhut-II/2005, tentang Pedoman Pemanfaatan Hutan Hak. Pada pasal 12 ayat (1), dinyatakan bahwa, pemanfaatan hutan hak dilakukan oleh pemegang hak atas tanah yang bersangkutan sesuai dengan fungsinya, kemudian dalam ayat (2) dinyatakan bahwa, pemanfaatan hutan hak sebagaimana dimaksud pada ayat (1), bertujuan untuk memperoleh manfaat yang optimal bagi pemegang hak dengan tidak mengurangi fungsinya.

Pada pasal 16 dinyatakan, bahwa tata cara pemanfaatan hutan hak sebagaimana dimaksud dalam Peraturan Menteri Kehutanan No. P.26/2005 pasal 13, pasal 14 dan pasal 15 diatur dengan peraturan Bupati/Walikota. Selanjutnya pada pasal 18 dinyatakan, bahwa Pemerintah Kabupaten/Kota menetapkan lebih lanjut petunjuk pelaksanaan tentang pemanfaatan hutan hak dengan mengacu kepada peraturan ini dan peraturan perundangundangan yang berlaku. Untuk penatausahaan hasil hutan peraturan perundang-undangan yang berlaku adalah Surat Keputusan Menteri Kehutanan Nomor 126/Kpts-II/2003, yang kemudian beberapa pasal dalam SK tersebut direvisi dengan Peraturan Menteri Kehutanan Nomor P.18/Menhut-II/2005, dan Peraturan Menteri Kehutanan Nomor P.51/MenhutII/2006, tentang Penggunaan Surat Keterangan Asal Usul Kayu (SKAU) Untuk Pengangkutan Hasil Hutan Kayu Yang Berasal Dari Hutan Hak. 
Penatausahaan hasil hutan di Kabupaten Cilacap berdasarkan tinjauan sudah berjalan dengan baik, terbukti dengan telah di buat dan diberlakukannya Peraturan Daerah (Perda) Kabupaten Cilacap Nomor 12, tahun 2001 tentang Retribusi Tebang di Kabupaten Cilacap, adapun isi dari perda tersebut menyangkut keseluruhan mengenai penatausahaan hasil hutan. Akan tetapi dengan berjalannya waktu dan perubahan kebijakan khususnya di sektor kehutanan, maka Perda tersebut perlu untuk di tinjau kembali dan disesuaikan isinya dengan peraturan perundangan yang berlaku pada saat ini, yaitu SK Menteri Kehutanan Nomor 126/Kpts-II/2003 tentang Penatausahaan Hasil Hutan. Peninjauan kembali perda tersebut mengingat beberapa pasal dalam perda tersebut belum disesuaikan dengan SK yang diterbitkan oleh Menteri Kehutanan, seperti dalam ijin permohonan penebangan atau pemanfaatan hasil hutan, permohonan dokumen angkutan, penerbitan SKSHH, dan lain sebagainya.

Guna menciptakan kondisi pemanfaatan potensi hasil hutan dari hutan rakyat yang dapat dipertanggungjawabkan diperlukan suatu mekanisme yang rasional dalam arti selain dapat dilaksanakan di lapangan, juga sebagai wujud pelayanan berupa terpenuhinya persyaratan legalisasi atas kepemilikan hasil hutan. Berdasarkan Undang-undang Nomor 32 Tahun 2004 tentang Pemerintahan Daerah, pelaksanaan urusan pemerintahan di daerah dilaksanakan berdasarkan azas otonomi daerah yang seluas-luasnya dengan pengakuan adanya hubungan hirarkis antara Pemerintah Pusat, Pemerintah Provinsi dan Pemerintahan Kabupaten / Kota. Atas dasar pernyataan tersebut di atas dalam pengaturan pemanfaatan hasil hutan kayu yang berasal dari hutan hak milik / rakyat, secara implisit Kepala Dinas Kehutanan Provinsi di tuntut untuk mengadakan pengaturan perihal pemanfaatan potensi hasil hutan kayu rakyat di wilayahnya sesuai dengan Permenhut Nomor P.26/MenhutII/2005 berupa Petunjuk Pelaksanaan (Juklak). Juklak di atas diharapkan dapat dijadikan pedoman yang kemudian dijabarkan lebih lanjut oleh pihak pemerintahan Kabupaten/Kota khususnya dalam dalam bentuk Petunjuk Teknis (Juknis) penyelenggaraan pelayanan penatausahaan kayu rakyat, sehingga pemanfaatan potensi hasil hutan dari hutan hak milik / rakyat dapat berjalan pada proses yang dapat dipertanggungjawabkan atau jelas lacak balaknya, dan efektivitas pelaksanaan penatausahaan hasil hutan kayu rakyat dengan baik dan benar.

\section{Surat Ijin Tebang (SIT)}

Peninjauan kembali atau penyesuaian isi Peraturan Daerah Kabupaten Cilacap Nomor 12 tahun 2001, tentang Retribusi Tebang Di kabupaten Cilacap, perlu dilakukan karena antara Perda yang dikeluarkan oleh Pemda Kabupaten Cilacap dengan SK Menteri Kehutanan Nomor 126/2003 terdapat perbedaan yang cukup mendasar dalam hal pemanfaatan hasil hutan di hutan hak / rakyat. Dalam pemberitahuan rencana penebangan, di dalam Perda Kabupaten Cilacap No. 12/2001, pasal 2 ayat (1) dinyatakan bahwa, setiap orang pribadi atau badan yang akan melakukan penebangan pohon kayu di daerah wajib terlebih dahulu mendapat ijin dari Bupati atau Instansi yang ditunjuk, sedangkan dalam SK Menteri Kehutanan No 126/2003, pasal 33, pemberitahuan rencana penebangan cukup diberitahukan kepada Kepala Desa atau Pejabat Setara yang diangkat oleh Kepala Dinas Provinsi dengan tembusan kepada Kepala Dinas Kabupaten/Kota. Pelimpahan kewenangan pemberitahuan rencana penebangan kayu rakyat kepada Kepala Desa setempat dimana tegakan pohon tersebut berada terutama dilatarbelakangi pada kenyataan, bahwa pihak yang lebih mengetahui potensi kayu rakyat adalah aparat desa, sehingga pemberitahuan rencana 
penebangan kayu rakyat kepada Kepala Desa atau pejabat yang setara tersebut akan lebih meningkatkan nilai obyektivitas dalam memberikan perijinan penebangan kayu rakyat kepada masyarakat.

Ketentuan mengenai pembuatan Surat Ijin Tebang (SIT) memang belum diatur secara rinci oleh Departeman Kehutanan, akan tetapi dalam pemanfaatan hasil hutan aturan main tersebut harus dibuat oleh pemerintah setempat, agar hasil hutan yang diperoleh benar-benar berasal dari hutan milik rakyat. Selain daripada itu juga untuk memperoleh manfaat yang optimal atas lahan hutan rakyat tersebut. Untuk lebih mengoptimalkan dalam pemanfaatan kayu rakyat oleh masyarakat dan untuk mempermudah dalam pemberian ijin pemanfaatan hutan rakyat, maka pemanfaatan kayu rakyat dari hutan rakyat dapat dikelompokan ke dalam dua (2) katagori (Syahadat, 2006), yaitu:

a. Pemanfaatan kayu rakyat untuk memenuhi kebutuhan kayu sendiri atau digunakan sendiri.

b. Pemanfaatan kayu rakyat untuk dikomersilkan atau diperjual belikan.

Untuk katagori kelompok pertama (a), yaitu kayu rakyat untuk keperluan sendiri, pengurusan ijinnya cukup melaporkan kepada Kepala Desa dan tembusannya kepada KCDK atau UPTD Dinas Kehutanan setempat. Akan tetapi apabila kayu rakyat tersebut akan dimanfaatkan untuk tujuan komersil atau diperjual belikan (katagori b), maka pemanfaatan kayu rakyat tersebut perlu diatur lebih lanjut oleh Dinas Kabupaten/Kota yang membidangi Kehutanan, seperti dalam pembuatan Surat Ijin Tebang (SIT), dokumen angkutan, dan lain sebagainya. Namun dalam pelaksanaannya sebaiknya diserahkan kepada pemerintah daerah (Kepala Desa, Camat, KCDK atau UPTD Dinas Kehutanan setempat), dasar pertimbangan permohonan SIT harus melalui KCDK atau UPTD Dinas Kehutanan Kabupaten/Kota adalah, KCDK atau UPTD merupakan perwakilan dari Dinas Kehutanan Kabupaten/Kota yang berada di tingkat kecamatan yang mengetahui tegakan kayu yang akan dimanfaatkan oleh masyarakat di seluruh wilayah Kabupaten/Kota, dan ini merupakan upaya dalam menjaga dan atau memastikan bahwa kayu rakyat yang akan dimanfaatkan tersebut bukan berasal dari kawasan hutan milik negara.

Permohonan ijin tebang di Kabupaten Cilacap sudah dibuat mekanisme / alur dan prosedur permohonan tersebut mengacu kepada Perda No. 12/2001, adapun mekanisme pembuatan SIT ini, adalah sebagai berikut:

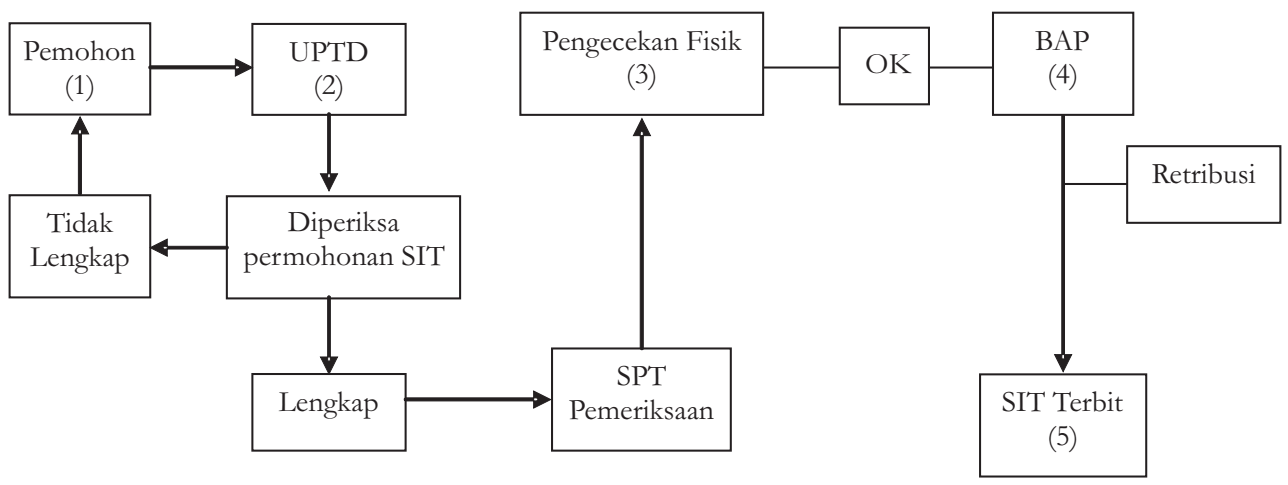

Gambar 2. Mekanisme/Alur Permohonan Ijin Tebang 


\section{Keterangan Gambar 2 :}

1) Pemohon mengajukan permohonan penerbitan SIT kepada Bupati $c q$ Kepala Dinas melalui Kepala UPTD Dinas Kehutanan dan Perkebunan setempat.

2) UPTD Dinas Kehutanan dan Perkebunan memeriksa permohonan penerbitan SIT,

- Apabila berkas persyaratan sudah lengkap maka UPTD menerbitkan Surat Perintah Tugas (SPT) pemeriksaan, adapun tim pemeriksa terdiri dari Staf UPTD dan atau Petugas Lapangan Setempat

- Apabila berkas persyaratan tidak lengkap surat permohonan dikembalikan ke pemohon.

3) Pengecekan Lapangan, meliputi kepelikan lahan dan tegakan, lokasi, jenis kayu, jumlah (volume) kayu, dan lain-lain.

4) Berdasarkan hasil pengecekan di lapangan apabila telah sesuai dengan ketentuan yang telah ditetapkan oleh Pemerintah Daerah Setempat, maka BAP pengecekan lapangan diterbitkan oleh Kepala UPTD.

5) Berdasarkan BAP pengecekan lapangan yang sudah dibuat, dan setelah pemohon membayar retribusi, SIT diterbitkan dan diserahkan kepada pemohon.

\section{Legalitas Kayu Rakyat}

Berdasarkan Peraturan Menteri Kehutanan Nomor P.26/2005 pasal 17, ayat (1) yang menyatakan bahwa semua hasil hutan kayu dan bukan kayu yang berupa rotan dan gaharu dari areal hutan hak yang akan digunakan dan atau diangkut kedaerah lainya dilengkapi dengan Surat Keterangan Asal Usul (SKAU) yang diterbitkan oleh Kepala Desa atau pejabat yang setara. Didalam Perda Kabupaten Cilacap No. 12/2001, masalah legalitas kayu sudah tercakup, akan tetapi belum secara rinci.

Untuk lebih mengoptimalkan penatausahaan hasil hutan dalam upaya menjaga Kelestarian Hutan sesuai dengan PP No. 34/2002, pejabat yang berwenang dalam menerbitkan bukti kepemilikan kayu rakyat atau SKAU dalam hal ini adalah Kepala Desa atau pejabat yang setara diberikan pelatihan setingkat pejabat penerbit lainnya seperti P2LHP, P2SKSHH, P3HH dan kemudian diberikan sertifikat serta Surat Ijin Penerbitan SKAU, sedangkan untuk pengendalian dan pengawasan terhadap pejabat tersebut dilakukan oleh Dinas Kabupaten/Kota setempat yang membidangi kehutanan.

\section{Penebangan Kayu Rakyat}

Pada pasal 35, ayat (1) SK Menteri Kehutanan No. 126/2003, dinyatakan bahwa Pemilik hutan hak/rakyat termasuk pemilik kebun yang memanfaatkan kayu bulat dari land clearing wajib membuat dan melaporkan realisasi penebangan / pemanenan dan pengangkutan kayu bulat dengan menggunakan format blanko LMKB. Kemudian pada ayat (2) dinyatakan bahwa laporan sebagaimana dimaksud pada ayat (1) disampaikan kepada Kepala Dinas Kabupaten/Kota dengan tembusan Kepala Dinas Provinsi.

Berdasarkan Perda Kabupaten Cilacap No. 12 tahun 2001, penebangan pohon dilakukan setelah SIT terbit, kemudian didalam melakukan penebangan pohon ada beberapa hal yang harus diperhatikan, seperti arah rebah tidak merusak tanaman muda, reklamasi dan atau menanam kembali sejumlah pohon yang ditebang. Setelah kayu ditebang pemilik kayu diwajibkan membuat Laporan Hasil Penebangan (LHP) dan Daftar Hasil Hutan (DHH). Apabila kita melihat pada ketentuan yang dibuat oleh Pemda Kabupaten Cilacap mengenai penebangan pohon sudah sesuai dengan ketentuan yang berlaku mengenai penatausahaan hasil hutan. Apabila kita gambarkan mekanisme atau alur penebangan kayu, adalah sebagai berikut: 


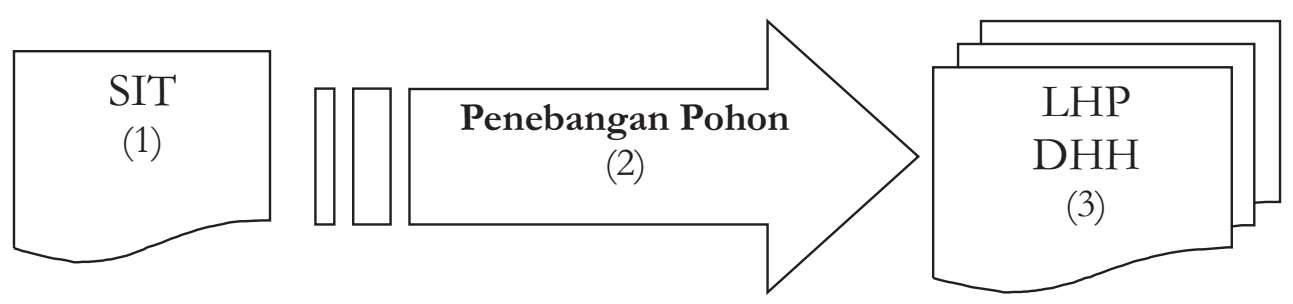

Gambar 3. Mekanisme/Alur Penebangan Kayu

\section{Keterangan :}

a. Setelah Surat Ijin Tebang (SIT) diterbitkan, maka pemohon melakukan penebangan pohon.

b. Didalam melakukan penebangan pohon ada beberapa ketentuan yang harus diperhatikan, seperti :

- Arah rebah tidak merusak tanaman muda

- Pemohon harus mengadakan reklamasi dan atau menanam kembali sejumlah pohon yang ditebang.

c. Laporan Hasil Penebangan (LHP) dan Daftar Hasil Hutan (DHH) kayu bulat harus memuat:

- Jenis kayu dan jumlah batang

- Diameter kayu dan volume kayu.

\section{Pengangkutan Kayu Rakyat}

Sehubungan dengan hasil hutan rakyat yang akan diangkut dan akan diterbitkan SKSHH nya, dalam SK Menteri Kehutanan No. 126/2005, Pasal 33 ayat (3) huruf (d), dinyatakan bahwa : Kayu yang akan diterbitkan SKSHH untuk diangkut/dijual ke industri pengolahan kayu wajib dilakukan pengukuran oleh petugas kehutanan yang berkualifikasi Penguji Hasil Hutan (PHH), dan kemudian dalam huruf (e), dinyatakan bahwa Hasil pemeriksaan dituangkan dalam Daftar Hasil Hutan dengan cap KR (DHH-KR), dengan prosedur sesuai dengan ketentuan yang berlaku dan ditanda tangani oleh petugas bersangkutan sebagai dasar penerbitan SKSHH oleh P2SKSHH. DHH-KR dibuat atas dasar hasil pemeriksaan yang dilakukan oleh Penguji Hasil Hutan (PHH), dan harus disahkan oleh petugas Kehutanan yang berkualitas Penguji Hasil Hutan (PHH). Hal ini merupakan dasar dalam permohohonan penerbitan SKSHH serta sesuai dengan mekanisme penatausahaan hasil hutan yaitu SK Menteri Kehutanan No. 126/2005 dan Permenhut No. P.18/2005.

Berdasarkan ketentuan teknis yang ada, bahwa setiap peredaran hasil hutan kayu rakyat wajib disertai dokumen pengangkutan, dan sesuai dengan pasal 16 ayat (1) SK Menteri Kehutanan No 126/2003, yang menyatakan bahwa : Setiap pengangkutan hasil hutan kayu dari lokasi penebangan/pemanenan di tempat tebangan atau dari TPn yang akan di angkut ke TPk hutan wajib menggunakan Daftar Pengangkutan (DP), yang diterbitkan oleh Petugas Perusahaan Pemegang IUPHHK, IPHHK atau ILS dengan menggunakan blanko model DK A. 202, kemudian dalam ayat (2) Daftar Pengangkutan dimaksud pada ayat (1) berfungsi sebagai dokumen pengangkutan antara dan bukti keabsahan hasil hutan. Di Kabupaten Cilacap sesuai dengan SK Bupati Kabupaten Cilacap Nomor 43 tahun 2004 tentang Petunjuk Pelaksanaan, Perda Kabupaten Cilacap Nomor 12 tahun 2001 tentang Retribusi Tebang di Kabupaten Cilacap. Pada pasal 5 dinyatakan bahwa setiap orang atau Badan Hukum dilarang melakukan pengangkutan kayu hasil tebangan untuk jenis-jenis tertentu tanpa disertai dengan 
legalisasi Tok kayu dan dokumen SKSHH. Pernyataan tersebut menunjukan perlu adanya ketegasan Pemda setempat dalam melaksanakan penatausahaan hasil hutan, khususnya dalam penertiban dokumen angkutan hasil hutan. Selain untuk memberikan kemudahan dalam melakukan pengangkutan kayu yang masih dalam satu wilayah Kabupaten Cilacap, Pemda setempat menerbitkan Surat Keputusan Bupati Daerah Nomor 151 tahun 2004, tentang Petunjuk Pelaksanaan Penerbitan Surat Keterangan Angkutan Kayu Lokal (SKAKL) di Kabupaten Cilacap. Penerbitan SKAKL tersebut tidak menyalahi peraturan penatausahaan hasil hutan yang diterbitkan oleh Departemen Kehutanan, karena menurut Permenhut No. P.18/2005, Pasal 20 ayat (6), dinyatakan bahwa : Pengangkutan kayu bulat, kayu olahan maupun HHBK yang karena suatu hal tidak efisien dalam pengangkutan disebabkan faktor alam atau hambatan dalam pengangkutan, maka pelaksanaan pengangkutan di atur secara khusus oleh Kepala Dinas Provinsi. Pernyataan tersebut menunjukkan bahwa penerbitan dokumen angkutan lain selain SKSHH dapat dilakukan dengan rekomendasi dari Dinas Provinsi setempat, untuk kasus di Kabupaten Cilacap memang tidak jelas, apakah penerbitan SKAKL tersebut sudah mendapat rekomendasi dari Dinas Kehutanan Provinsi atau belum, akan tetapi pada dasarnya untuk menciptakan penatausahaan hasil hutan yang baik, tertib, lancar dan aman penerbitan SKAKL tersebut tidak menyalahi peraturan penatausahaan hasil hutan yang berlaku saat ini.

Di dalam Permenhut No. P.18/2005 pasal 20, mengenai tata cara penerbitan SKSHH, dinyatakan bahwa Pemohon SKSHH mengajukan permohonan penerbitan SKSHH kepada P2SKSHH dan tembusannya kepada Kepala Dinas Kehutanan setempat, maka atas permohonan penerbitan SKSHH tersebut P2SKSHH melakukan pengecekan fisik dan administrasi, apabila hasil pengecekan fisik dan administrasi telah sesuai dengan DHH yang menyertai kayu tersebut maka di buatkan BAP pemeriksaan, dan atas dasar BAP pemeriksaan dan sudah membayar kewajiban kepada negara (PSDH-DR, Retribusi), maka P2SKSHH menandatangani DHH dan menerbitkan SKSHH, dan atas dasar SKSHH yang telah diterbitkan, selanjutnya SKSHH tersebut disampaikan kepada pejabat eselon III yang membidangi kehutanan di wilayah kerja P2SKSHH untuk diketahui dan disetujui. Pernyataan diketahui dan disetujui oleh pejabat eselon III di Dinas Kabupaten/Kota menimbulkan pertentangan baik oleh Pejabat yang menandatangani SKSHH tersebut, maupun pemohon / pengguna SKSHH itu sendiri (Syahadat, 2006), alasannya adalah:

1) Jarak antara Pejabat eselon III yang menandatangani untuk mengetahui dan menyetujui SKSHH dengan fisik kayu yang akan diangkut tidak selamanya dapat dijangkau dengan mudah, sehingga dalam pelaksanaanya sulit untuk dilakukan oleh pejabat tersebut yang mempunyai tugas-tugas rutin dan padat.

2) Pemohon penerbitan SKSHH tidak hanya dari satu daerah saja, akan tetapi dari beberapa daerah yang masih dalam satu wilayah Dinas Kehutanan Kabupaten/Kota setempat, sehingga dalam pelaksanaan pengecekan fisik yang dilakukan oleh pejabat tersebut tidak mungkin dilakukan secara bersamaan.

3) Untuk pengurusan penerbitan SKSHH membutuhkan waktu yang cukup lama, sementara kayu tersebut harus dikirim secepatnya, karena pemohon terikat oleh kontrak kerja antara penjual dan pembeli yang harus dipenuhi agar tidak mendapat sanksi kerja.

4) Blanko SKSHH tidak selalu tersedia, untuk permohonan blanko saja memerlukan waktu yang lama, karena pendistribusian blanko dilakukan oleh Dinas Provinsi, sedangkan yang mencetak blanko SKSHH tersebut adalah Dirjen BPK. Adapun pemberian blanko kepada pemohon SKSHH berdasarkan kebutuhan yang dimintakan oleh pemohon 
melalui P2SKSHH, dan untuk permohonan blanko tersebut tidaklah mudah, serta dalam pengurusannya lebih 1 (satu) hari.

Dari keadaan atau kondisi seperti tersebut di atas dikhawatirkan adanya praktek penatausahaan hasil hutan yang tidak benar/tidak sesuai dengan SK Menteri Kehutanan No. 126/2003 dan Permenhut No. P.18/2005. Untuk menghindari adanya praktek penatausahaan hasil hutan yang tidak benar atau tidak sesuai dengan ketentuan yang berlaku, khususnya yang menyangkut pejabat eselon III dalam pengesahan SKSHH pada Dinas Kabupaten/Kota yang membidangi kehutanan, maka Dinas Kehutanan dan Perkebunan Kabupaten Cilacap melakukan upaya untuk mengantisipasi atau menghindari hal tersebut dengan menerbitkan SK Kepala Dinas Nomor 522.2/0489/26.4/2005 tertanggal 30 Juli 2005 tentang Penunjukan Pejabat yang berwenang untuk mengetahui dan menyetujui penerbitan SKSHH Kabupaten Cilacap, selain daripada itu penerbitan SK tersebut untuk memutus rantai birokasi yang panjang dalam permohonan penerbitan dokumen SKSHH yang tidak efisien dan tidak efektif. Penerbitan SK tersebut di atas selama dalam pelaksanaannya tidak tidak mempunyai maksud atau tujuan lainnya, atau substansinya tidak menyimpang dari ketentuan peraturan penatausahaan hasil hutan yang berjalan saat ini, maka penerbitan SK tersebut dapat dilaksanakan apalagi diperkuat dengan adanya undang-undang otonomi daerah.

Untuk masa yang akan datang dalam pengangkutan kayu rakyat akan diberlakukan dokumen angkutan lain selain SKSHH yang dicap KR, yaitu Surat Keterangan Asal Usul Kayu (SKAU) sebagai dokumen angkutan kayu rakyat resmi yang diterbitkan oleh Kepala Desa/Lurah atau pejabat yang setara, sesuai dengan Peraturan Menteri Kehutanan Nomor P.51/Menhut-II/2006, akan tetapi dalam Permenhut tersebut pada pasal (4), huruf (a), jenis kayu yang akan diangkut masih terbatas pada 3 (tiga) jenis kayu saja, yaitu kayu Sengon, kayu Karet, dan kayu Kelapa, sedangkan untuk jenis kayu lainnya akan ditetapkan oleh Menteri Kehutanan atas dasar usulan dari masing-masing Dinas Propinsi berdasarkan hasil inventarisasi jenis, potensi dan lokasi penyebaran kayu (Pasal 4, huruf b).

Sesuai dengan pasal 11, ayat (2) Permenhut No 51/2006, dinyatakan bahwa : Dengan ditetapkan peraturan ini, maka ketentuan Pasal 33, Pasal 34, dan Pasal 35 Keputusan Menteri Kehutanan Nomor 126/Kpts-II/2003, dinyatakan tetap berlaku untuk jenis-jenis kayu diluar jenis-jenis kayu yang ditetapkan sebagaimana dimaksud pada pasal 4 dalam peraturan ini. Kemudian pada ayat (3) dinyatakan bahwa peraturan ini berlaku sejak tanggal ditetapkan dan mempunyai daya laku efektif mulai 60 (enam puluh) hari kerja terhitung sejak ditetapkannya peraturan ini (Peraturan ini baru ditetapkan pada tanggal 10 Juli 2006).

\section{Kelembagaan Kayu Rakyat}

Dalam Peraturan Menteri Kehutanan No. P.26/2006 pasal (24) ayat (1) dinyatakan bahwa Pemerintah Pusat, Pemerintah Provinsi, Pemerintah Kabupaten/Kota berkewajiban untuk mengembangkan hutan hak melalui pengembangan kelembagaan, kemudian pada ayat (2) dinyatakan bahwa, pengembangan kelembagaan sebagaimana dimaksud pada ayat (1) terdiri dari kegiatan pembangunan dan penguatan kelembagaan masyarakat dan sistem usaha.

Permasalahan yang ada di tingkat petani, adalah petani membutuhkan dana untuk keperluan yang mendesak (menyekolahkan anak, menikahkan anak dan lain sebagainya), sedangkan untuk memenuhi kebutuhan tersebut petani menjual pohon/kayu yang ia miliki dengan cara ijon atau lainnya kepada para tengkulak, padahal apabila dilihat dari umur kayu tersebut belum waktunya untuk di tebang (belum masak tebang). Untuk dapat menanggulangi hal tersebut alangkah baiknya apabila dibentuk suatu wadah kelembagaan di tingkat petani 
seperti Koperasi Pemilik Hutan Rakyat (KPHR), yang dapat membantu petani pada saat petani tersebut membutuhkan atau memerlukan dana, sehingga petani tidak menjual kayunya dengan harga yang rendah. Selain daripada itu dengan keberadaan KPHR diharapkan harga kayu rakyat stabil dan, persediaan kayu rakyat terjamin, mengingat KPHR dapat melakukan negosiasi dengan dengan pihak luar (pemohon kayu) seperti IPKH, IPK, ILS dan lain sebagainya mengenai harga kayu rakyat. Di Kabupaten Cilacap masalah kelembagaan di tingkat petani belum ada khususnya kelembagaan yang berkaitan dengan permasalahan penata-usahaan hasil hutan.

\section{KESIMPULAN DAN SARAN}

\section{A. Kesimpulan}

1. Penatausahaan hasil hutan di hutan hak/rakyat belum secara rinci diatur dalam perundang-undangan. Prosedur / tata cara pemanfaatan hasil hutan di hutan hak/rakyat belum jelas seperti dalam permohonan Surat Ijin Tebang (SIT), penebangan kayu, dan lain sebagainya.

2. Pelaksanaan Penatausahaan Hasil Hutan di Kabupaten Cilacap sudah berjalan, berdasarkan Perda Kabupaten Cilacap No 12/2001 dan SK Bupati No. 43/2004.

3. Potensi dan kontribusi kayu yang berasal dari hutan rakyat untuk memenuhi kebutuhan bahan baku industri perkayuan di Indonesia cukup besar, hal tersebut dapat dilihat di Provinsi Jawa Tengah dari kebutuhan bahan baku kayu 6 juta $\mathrm{M}^{3} /$ tahun untuk industri perkayuan, baru terpasok sekitar 2,9 juta $\mathrm{M}^{3}$ / tahun yang terdiri dari Perum Perhutani Unit I Jawa Tengah sebesar $600.000 \mathrm{M}^{3} /$ tahun, hutan rakyat sebesar $1.700 .000 \mathrm{M}^{3} /$ tahun dan sisanya dipasok dari luar jawa.

4. Sesuai dengan SK Bupati Nomor 43/2004 tentang Petunjuk Pelaksanaan, Perda Kabupaten Cilacap Nomor 12/2001 tentang Retribusi Tebang di Kabupaten Cilacap, pada pasal 5 dinyatakan bahwa setiap orang atau badan hukum dilarang melakukan pengangkutan kayu hasil tebangan untuk jenis-jenis tertentu tanpa disertai dengan legalisasi Tok kayu dan dokumen SKSHH.

5. Pemda Kabupaten Cilacap dalam melaksanakan penatausahaan hasil hutan, khususnya dalam penertiban dokumen angkutan hasil hutan, untuk memberikan kemudahan dalam melakukan pengangkutan kayu yang masih dalam satu wilayah Kabupaten Cilacap, menerbitkan Surat Keputusan Bupati Daerah Nomor 151/2004 tentang Petunjuk Pelaksanaan Penerbitan Surat Keterangan Angkutan Kayu Lokal (SKAKL) di Kabupaten Cilacap.

\section{B. Saran}

1. Penatausahaan hasil hutan di hutan hak/rakyat masih perlu untuk disempurnakan, dalam rangka perbaikan pelayanan publik terhadap pengolahan hutan agar pengolahan hutan dapat lebih efisien, efektif, dan lestari.

2. Perlu dibuatkan aturan atau petunjuk pelaksanaan (juklak) dan atau petunjuk teknis (juknis) dari sistim penatausahaan hasil hutan di hutan hak/rakyat agar tercipta penyelenggaraan hasil hutan hak/rakyat, tertib lancar, efisien dan bertanggung jawab dengan potensi yang dimiliki. 
3. Untuk meninjau kembali atau merevisi Peraturan Daerah Kabupaten Cilacap Nomor 12 tahun 2001, tentang Retribusi Ijin Tebang di Kabupaten Cilacap.

4. Untuk lebih baik dalam penatausahaan hasil hutan dimasa yang akan datang, diharapkan Departemen Kehutanan mengeluarkan pedoman yang meliputi tata cara permohonan pembuatan Surat Ijin Tebangan (SIT). Atas dasar pedoman tersebut Dinas Provinsi membuat Petunjuk Pelaksanaan (Juklak) yang kemudian ditindak lanjuti oleh Dinas Kabupaten/Kota setempat dengan membuat Petunjuk Teknis (Juknis) yang digunakan sebagai dasar dalam pembuatan SIT.

5. Kelembagaan di tingkat petani kayu rakyat seperti Koperasi Petani Hutan Rakyat (KPHR) harus segera dibentuk, agar tercipta penatausahaan hasil hutan di hutan rakyat yang baik, bertanggungjawab, lestari, dan dapat memberikan insentif lebih untuk para petani.

\section{DAFTAR PUSTAKA}

Keputusan Direktur Jenderal Pengusahaan Hutan No.521/Kpts/IV-Tib/1985, tanggal 4 Desember 1985. Tentang Petunjuk Teknis Tata Usaha Kayu. Departemen Kehutanan, Jakarta.

Keputusan Menteri Kehutanan No.402/Kpts-IV/1990, tanggal 7 Agustus 1990. Tentang Tata Usaha Kayu. Departement Kehutanan, Jakarta.

Undang-undang Nomor 41 Tahun 1999, tanggal 30 September 1999. Tentang Kehutanan, Jakarta.

Keputusan Menteri Kehutanan dan Perkebunan No. 316/Kpts-II/1999, tanggal 7 Mei 1999. Tentang Tata Usaha Hasil Hutan. Departemen Kehutanan dan Perkebunan, Jakarta.

Keputusan Menteri Kehutanan No.126/Kpts-II/2003, tanggal 4 April 2003. Tentang Penatausahaan Hasil Hutan. Departemen Kehutanan, Jakarta.

Peraturan Pemerintah No. 6 Tahun 2007, tanggal 8 Januari 2007. Tentang Tata Hutan dan Penyusunan Rencana Pengelolaan Hutan, Serta Pemanfaatan Hutan. Departemen Kehutanan, Jakarta.

Peraturan Menteri Kehutanan No.P.18/Menhut-II/2005, tanggal 13 Juli 2005. Tentang Perubahan Ketiga SK Menteri Kehutanan No. 126/Kpts-II/2003, Tentang Penatausahaan Hasil Hutan. Departemen Kehutanan, Jakarta.

Peraturan Menteri Kehutanan No.P.26/Menhut-II/2005, tanggal 6 Agustus 2005. Tentang Pedoman Pemanfaatan Hutan Hak. Departemen Kehutanan, Jakarta.

Peraturan Menteri Kehutanan No.P.51/Menhut-II/2006, tanggal 10 Juli 2006. Tentang Penggunaan Surat Keterangan Asal Usul (SKAU) Untuk Pengangkutan Hasil Hutan Kayu Yang Berasal Dari Hutan Hak. Departemen Kehutanan, Jakarta.

Keputusan Bupati No.43 tahun 2004. Tentang Petunjuk Pelaksanaan Perda Kabupaten Cilacap No. 12/2001 tentang Retribusi Tebang, Cilacap.

Anonim, 2004, Statistik Kehutanan Provinsi Jawa Tengah Tahun 2004. Dinas Kehutanan Provinsi Jawa Tengah, Semarang. 
Anonim, 2004, Potensi Kayu Untuk Industri Di Jawa Tengah. Dinas Kehutanan Provinsi Jawa Tengah, Semarang.

Anonim, 2006, Data Profil Daerah Kabupaten Cilacap s/d Tahun 2006 No. Dinas Kehutanan Kabupaten Cilacap, Cilacap.

Keputusan Bupati No.151 tahun 2004. Tentang Petunjuk Pelaksanaan Penerbitan Surat Keterangan Angkutan Kayu Lokal (SKAKL), Cilacap.

Keputusan Kepala Dinas Kehutanan Kabupaten Cilacap No.522.2/0489/264/2005, tanggal 30 Juli 2005. Tentang Penunjukan Pejabat Yang Berwenang Untuk Mengetahui dan Menyetujui Penerbitan SKSHH Kabupaten Cilacap, Cilacap.

Peraturan Daerah Kabupaten Cilacap No.12 tahun 2001. Tentang Retribusi Tebang di Kabupaten Cilacap, Cilacap.

Syahadat, E. 2006. Penatausahaan Hasil Hutan Di Hutan Rakyat Sebagai Dasar Acuan Pemanfaatan Hutan Rakyat, Naskah Jurnal Sosial Ekonomi dan Kebijakan Kehutanan, Bogor.

Syahadat, E, Sianturi, A. 2006 Kajian Penyempurnaan Tata Usaha dan Tata Niaga Kayu Rakyat (Kasus di Provinsi Jawa Barat). Makalah Presentasi Konsultasi Publik Project ITTO PD 271/04 REV.3 (F), Bandung. 